\title{
Conjunctive Planning of Surface and Groundwater Resources in Canal Command Area of Odisha-A Success Story
}

\author{
Ranu Rani Sethi-R.B.Singandhupe ${ }^{1}$-Ashwani Kumar \\ Directorate of Water Management, Bhubaneswar, Odisha-751023 \\ ${ }^{I}$ Central Institute for Cotton Research, Nagpur, Maharashtra
}

\begin{abstract}
Conjunctive planning of irrigation through bore wells, dug wells and water harvesting structures along with farmers' participatory approach in Pattamundai canal command area of Odisha could increase cropping intensity from $151 \%$ to $300 \%$ with high value and less water requirement crops. Interventions showed that during long dry spell period in kharif season and non availability of canal water, use of groundwater up to $20 \%$ of the crop water demand could enhance crop yield up to $21 \%$. Utilizing water from dug well, for three crops (short duration paddy- potato/ radish- bitter gourd) in a year recorded highest net return of Rs 87368/ha against two crops (paddy - brinjal) without depletion of groundwater level. Further, highest water productivity ( $\mathrm{kg}$ fruit yield $/ \mathrm{m}^{3}$ of water used) was observed in potato (6.67-8.41) followed by brinjal (4.06-4.42).
\end{abstract}

Keywords: Groundwater dug well, irrigation, canal command

\section{Introduction}

Coastal areas are always under high stress due to population rise, which leads to higher demand of water for domestic, agriculture and industrial requirements. Odisha state located in Eastern part of India receives average annual rainfall of $1492.8 \mathrm{~mm}$, covered with large river and canal network under 5 major river basins, but most of its agricultural land remains fallow during non monsoon period resulting low cropping intensity of $161 \%$ only (Anonymous, 2008). Among various causes, major reasons are the non availability of required amount of water in river and canal system during rabi (November to February) and summer (March - May) period. Though canal is being operated for very short period in rabi season, due to non uniform distribution, most of the canal command area does not receive the required amount of water. Considering the feasibility of groundwater use for irrigation purposes, there is a scope to utilize the same for increasing the cropping intensity. The average groundwater development in the State is only $26.14 \%$ with wide spatial variations (CGWB, 2009). In this situation, greater attention can be given to water management in irrigated as well as in rainfed agriculture. Conjunctive use of surface and groundwater has been proved as one of the options to optimize water resource planning to increase the crop productivity. Many studies have been carried out based on the conjunctive management of groundwater and surface water (Cummings and Winkle, 1974, Khepar and Chaturvedi, 1982, Panda et al., 1985; Bredehoeft and Young, 1983) to increase the cropping intensity of the area. At the resource level, groundwater pumping for irrigation used in conjunction with surface water provides benefits that increase the water supply or mitigate undesirable fluctuations in the supply (Tsur, 1990). The optimal cropping pattern and area allocation with respect to availability of water resources (both surface and groundwater) were obtained for different seasons by using an optimization model (Sethi et al., 2002). On comparing the surface and groundwater irrigation in India as whole, the share of surface water has declined over the period of time, which leads to non availability of water in the canal system. Simultaneously tube wells have become the largest single source of irrigation water in India (Shankar, et al. 2011). Rainfall analysis of Odisha showed that out of total rainfall, $1295.7 \mathrm{~mm}(86.8 \%)$ is received during June- October, $98.6 \mathrm{~mm}(6.6 \%)$ during November to March and rest amount $98.5 \mathrm{~mm}(6.6 \%)$ during April and May. With respect to crop water demand, annual evaporative demand is $1657.8 \mathrm{~mm}$. This total annual crop evaporative demand (ETo) is higher by $11 \%$ over the water available through rain alone. This erratic distribution of rainfall caused variation in overall crop production. The evaporative demand during June to October (kharif season) is only $627.3 \mathrm{~mm}$ and rainfall is $1295.7 \mathrm{~mm}$, showing surplus of $106.5 \%$ over demand. During rabi season, the evaporative demand is $604.3 \mathrm{~mm}$ resulting a deficit of $83.7 \%$ and during summer month (April -May) the evaporative demand is 426 $\mathrm{mm}$ which is deficit of $76.9 \%$. Ion considering the coastal districts, availability of water through rain during kharif (June to October) is quite high ( $1042.6 \mathrm{~mm}$ to $1278 \mathrm{~mm}$ ) than the crop evaporative demand (614.4 $\mathrm{mm}$ to $657.1 \mathrm{~mm}$ ). The excess rain water over crop demand during kharif season causes severe problem of unfavorable edaphic environment (water logging) in agricultural crop production. These areas are dominated by alluvium formation with high yield potential of 5- 40 litre per second. Hence there is enormous scope to utilize these resources effectively in conjunction with surface irrigation system to increase cropping intensity and water productivity. It has been observed that in alluvial areas, the authority and capacity for water-resources management are mainly retained in surface-water-oriented agencies, because of the historical relationship with 
the development of irrigated agriculture (Foster and Steenbergen (2011). A number of researchers have assessed and confirmed the gains to be made from conjunctive use management (Shah et al, 2006). So this paper aims to deals with estimation of water budget in a canal command area and conjunctive planning of surface and groundwater resources to increase the overall cropping intensity through a case study.

\section{Study area}

The study was conducted in distributory no. $5 \mathrm{a}, 5 \mathrm{~b}$ and minor $5 \mathrm{~b}$ with cultural command area of 272.353 ha, 388.903 ha and 92.673 ha respectively with total command area of 753.93 ha. The area falls under Pattmundai canal in Mahanga block of Cuttack district of Odisha. Usually canal is being operated during July to November every year for major kharif paddy and between January to February during rabi season for green gram and black gram. Nearly 12 villages are covered under the command area and 749.93 ha $(64 \%$ of the total cultivated area) is being irrigated. During the kharif season, $71 \%$ to $87 \%$ of the area is covered with paddy and rest with Jute, vegetable and spices. After harvesting kharif crops, farmers grow vegetable, pulses, and groundnut and oil seeds. But the major crops are green gram and black gram either on residual soil moisture or with heavy pre sowing irrigation through canal which is released for short period during January -February month every year. But average yield of paddy is within 2.2-2.5 t/ha in tail reach, 2.5-2.7 t/ha in middle reach and 2.7-3.0 t/ha in head reach, and green gram yield ranges within 0.25-0.625 t/ha in different reaches of the canal command area.

\section{Methodology}

Preliminary survey was carried out to quantify water availability during kharif and rabi seasons. Details about the canal release pattern, availability of canal water to the farmers of head, middle and tail reach, cropping pattern, crop yield were collected from different sources like District Agriculture Office and Irrigation Department, Cuttack. Village wise information was collected from questioners' survey. Soil samples from different village under the canal command area were collected from soil depths of 0-15, 15-30, 30-45 and 45-60 $\mathrm{cm}$ and analyzed for textural class. The reference crop ET demand gives us an idea for planning available water resources to be used effectively for crop production in selected location. For assessing crop ET demand of this command area the daily crop evaporative demand (reference evapotranspiration) for the period from April 2008March 2009 and up to summer crop growing period was computed by Penman Monteith methods (FAO 56), by considering all weather parameters like temperature (maximum, minimum) relative humidity, wind speed, sunshine hours. For development of water resources on farmer's participatory approach, Gangadhar village was selected by involving 54 farmers of that area. The bore well, dug wells and water harvesting structures were constructed in farmers' field on participatory mode with an agreement that, the farmer will provide irrigation water to the adjoining farmers. Fifty percent expenditure was borne by the farmer and rest was from the project side. Selection of sites for construction of these structures, were based on Electrical Resistivity Survey and availability of water bearing zones. Finally impact of these structures was assessed based on change in cropping pattern, crop yield and water productivity of those areas.

\section{Water availability during $k$ harif and rabi season \\ III. Results and discussion}

During 2007-2008, Pattamundai canal was operated in kharif season for 129 days period during 12.07.2007 to 21.11.2007. In total command area of 753.93 ha, canal water available was 1971 ha-m and water

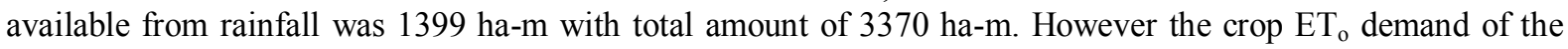
command area was only 211.74 ha-m. Excess amount of 3158.2 ha-m water causes problem of water logging and increase of groundwater level to shallow depth in head reach areas. After harvest of kharif paddy, canal water was released for 19 days period during 12.01.2008 to 31.01.2008 because of heavy rains in between and about 291 ha-m water was released excluding 26.17 ha-m rainfall. Total amount of water available through canal+ rainfall was 317.07 ha-m as against 36.30 ha- $\mathrm{m}$ crop water demand. Since rabi crop is generally continued up to March-April, there is substantial deficit of water. This deficit of water can be only fulfilled with groundwater once groundwater structure is developed.

During 2008-2009, canal water was released on 27.7.2008 and water flow in the distributaries was monitored at frequent interval at specific distance of the distributaries till the canal water supply was continued. During kharif season the canal water was continued up to 24.11.2008 for 124 days. During rabi season the water was released on 12.1.2009 and closed on 24.2.2009. The total duration of water flow was 43 days. The canal water is specifically released for rabi green gram as majority of the farmers grow this crop with pre-sowing heavy irrigations.

During 2009-2010, canal water was released on 17.72009 and was continued up to 15.11.2009. On an average of five observations on discharge rate of water in distributory, the discharge rate at head reach was 0.775 cumec in distributory $5 \mathrm{a}, 0.699$ cumec in $5 \mathrm{~b}$ and 0.225 cumec in minor of $5 \mathrm{~b}$. The flow rate was reduced 
as the distance from head reach increased. But at tail reach, the flow rate was very low even during August and September 2009. This clearly shows that the reduction in flow rate at tail reach is very high and it ranges from $8.5 \%$ at $0.2 \mathrm{~km}$ away from main outlet to $79.3 \%$ at $5 \mathrm{~km}$ away from main outlet. In distributory no. $5 \mathrm{~b}$ and minor of $5 \mathrm{~b}$, the reduction in flow rate of water ranged from $32.6 \%$ at $1.5 \mathrm{~km}$ away from main outlet to $64.9 \%$ at $4.5 \mathrm{~km}$ away from main outlet. In minor of $5 \mathrm{~b}$, the reduction was $67.7 \%$. During rabi season the water was released on 12.1.2010 and closed on 27.2.2010.The total duration of water flow was 46 days. The flow rate on an average of three observations were 0.715 cumec at head reach and 0.090 cumec at $5 \mathrm{~km}$ away from head reach in distributory no.5a and 0.735 cumec at head reach and 0.315 cumec at $4.5 \mathrm{~km}$ away from head reach in distributory no. $5 \mathrm{~b}$. In minor of $5 \mathrm{~b}$, it was only 0.218 cumec. Thus there was substantial reduction of flow rate in both the distributory as compared to head reach and the extent of reduction was $3.2 \%$ at $0.2 \mathrm{~km}$ away from source of outlet to $83.3 \%$ at $5 \mathrm{~km}$ away from source in distributory no. $5 \mathrm{a}$ and $24.4 \%$ at $1.5 \mathrm{~km}$ to $47.2 \%$ at 4.5 $\mathrm{km}$ away from source in distributory no. $5 \mathrm{~b}$. In minor of $5 \mathrm{~b}$, the reduction in flow of water was $55.7 \%$.

\section{Water budget for the canal command area}

Considering the growing period of paddy from June to November, the crop water demand is 553.4 ha$\mathrm{m}$ (Table 1). Average water available through rainfall during above period is $1326.0 \mathrm{ha}-\mathrm{m}$ and through canal water at head reach is 810 ha-m in distributory no. $5 \mathrm{a}$, and $669.1 \mathrm{ha}-\mathrm{m}$ in distributory no.5 b during canal operation period. However in tail reach, the availability of water is quite low i.e $166.2 \mathrm{ha}-\mathrm{m}$ and $223.7 \mathrm{ha}-\mathrm{m}$ in respective reaches. During winter and summer season, the crop water demand was $535.6 \mathrm{ha}-\mathrm{m}$ and water available through rainfall water was $114.1 \mathrm{ha}-\mathrm{m}$. However the water available through canal operation period of 46 days was $284.2 \mathrm{ha}-\mathrm{m}$ in distributory no. $5 \mathrm{a}$ and $120.7 \mathrm{ha}-\mathrm{m}$ in distributory no. $5 \mathrm{~b}$ at head reach point. However it was very low at tail reach point. Hence due to low availability of canal water the best possibility to take up rabi and summer in this command area is to develop groundwater structure on participatory basis and increase cropping intensity.

Table 1: Water budget in canal command area during 2009-2010

\begin{tabular}{|c|c|c|c|c|}
\hline Month & $\begin{array}{c}\text { Rainfall } \\
\mathrm{mm}\end{array}$ & $\begin{array}{c}\text { Water available through } \\
\text { rainfall, ha-m }\end{array}$ & $\begin{array}{c}\text { Monthly crop water } \\
\text { demand, mm }\end{array}$ & $\begin{array}{c}\text { Monthly crop water demand, } \\
\text { ha-m }\end{array}$ \\
\hline April 2009 & 0 & 0.0 & 186.37 & 140.5 \\
\hline May 2009 & 217.9 & 164.3 & 215.56 & 162.5 \\
\hline June 2009 & 63.1 & 47.6 & 164.96 & 91.4 \\
\hline July2009 & 526.2 & 396.7 & 121.21 & 89.1 \\
\hline August 2009 & 314.4 & 237.0 & 118.15 & 82.9 \\
\hline Sept.2009 & 287.3 & 216.6 & 109.91 & 85.2 \\
\hline Oct.2009 & 81.4 & 61.4 & 113.06 & 80.5 \\
\hline Nov.2009 & 53.6 & 40.4 & 106.73 & 71.5 \\
\hline Dec.2009 & 0 & 0.0 & 94.81 & 69.9 \\
\hline Jan.2010 & 1.4 & 1.1 & 92.75 & 73.1 \\
\hline Feb.2010 & 0 & 0.0 & 96.96 & 95.0 \\
\hline March.2010 & 10.2 & 7.7 & 125.98 & 1165.9 \\
\hline Total & 1555.5 & 1172.7 & 1546.4 & 112.5 \\
\hline April 2010 & 14.6 & 11.0 & 149.2 & 113.6 \\
\hline May 2010 & 125.1 & 94.3 & 150.68 & 88.3 \\
\hline June 2010 & 188.6 & 142.2 & 117.17 & \\
\hline
\end{tabular}

Soil characterization

Soil characterization in middle and tail reach of the command area showed that clay content is comparatively higher than at head reach in $30-45$ and $45-60 \mathrm{~cm}$ soil depth (Table-2). The soil is not well drained as compared to head reach of the canal command area. The soil moisture characteristic curve help us to know the available moisture in different soil layer for adopting irrigation scheduling in different crops and to assess percent depletion of available soil moisture in root zone. Similarly in command area, it is essential to know the actual soil moisture available in soil profile to follow the amount of water to be released so that it may not get waterlogged due to poor drainage. 
Table 2: Soil textural properties

\begin{tabular}{|c|c|c|c|c|c|}
\hline Location & Soil properties & $0-15 \mathrm{~cm}$ & $15-30 \mathrm{~cm}$ & $30-45 \mathrm{~cm}$ & $45-60 \mathrm{~cm}$ \\
\hline \multirow[t]{4}{*}{ Head reach } & Sand (\%) & 85.84 & 81.84 & 79.84 & 80.84 \\
\hline & Silt (\%) & 5.70 & 7.7 & 8.7 & 7.7 \\
\hline & Clay (\%) & 11.46 & 10.46 & 11.46 & 11.46 \\
\hline & Class & Loamy sand & Sandy loam & Sandy loam & Sandy loam \\
\hline \multirow{2}{*}{$\begin{array}{l}\text { Middle } \\
\text { reach }\end{array}$} & Sand $(\%)$ & 77.84 & 77.84 & 79.84 & 77.84 \\
\hline & Silt (\%) & 10.7 & 13.4 & 7.7 & 6.7 \\
\hline \multirow[t]{4}{*}{ Tail } & Sand (\%) & 75.84 & 79.84 & 79.84 & 80.84 \\
\hline & Silt (\%) & 11.7 & 7.7 & 7.7 & 6.7 \\
\hline & Clay (\%) & 12.46 & 12.46 & 12.46 & 12.46 \\
\hline & Class & loam & Loam & Loam & Sandy loam \\
\hline
\end{tabular}

Groundwater table depth

The groundwater table fluctuation showed that during pre-monsoon period, it the ranged within $2.0 \mathrm{~m}$ to $3.18 \mathrm{~m}$, during post monsoon period it ranged from $2.0 \mathrm{~m}$ to $3.2 \mathrm{~m}$ and it remained about $2 \mathrm{~m}$ during monsoon season (Table 3). The data on groundwater fluctuations showed that the groundwater table during the month of May was at deeper depth, thereafter due to receipt of rainfall and release of canal water, the groundwater table remained at shallow depth. During the post monsoon season also the groundwater table depth was at shallow depth because of release of canal water in the month of January 2010 and continued up to February 2010. The detail statistical analysis of the groundwater table fluctuations indicated that there is abundant amount of groundwater at shallow depth in all the canal command area.

Table 3: Statistical analysis of water table depth (meter)

\begin{tabular}{|c|c|c|c|c|c|c|c|c|c|}
\hline \multirow{2}{*}{$\begin{array}{l}\text { Parameter } \\
\mathrm{s}\end{array}$} & \multicolumn{3}{|c|}{$2007-08$} & \multicolumn{3}{|c|}{ 2008-09 } & \multicolumn{3}{|c|}{$2009-2010$} \\
\hline & $\begin{array}{l}\text { Mar-May } \\
\text { (P.M) } \\
\text { m }\end{array}$ & $\begin{array}{l}\text { June-Oct } \\
\text { (M) } \\
\text { m }\end{array}$ & $\begin{array}{l}\text { Nov-Feb } \\
\text { (PostM) } \\
\mathrm{m}\end{array}$ & $\begin{array}{l}\text { Mar-May } \\
\text { (P.M) } \\
\text { m }\end{array}$ & $\begin{array}{l}\text { June-Oct } \\
\text { (M) } \\
\mathrm{m}\end{array}$ & $\begin{array}{l}\text { Nov-Feb } \\
\text { (PostM) } \\
\mathrm{m}\end{array}$ & $\begin{array}{l}\text { Mar-May } \\
\text { (P.M) } \\
\text { m }\end{array}$ & $\begin{array}{l}\text { June-Oct } \\
\text { (M) } \\
\mathrm{m}\end{array}$ & $\begin{array}{l}\text { Nov-Feb } \\
\text { (PostM.) } \\
\mathrm{m}\end{array}$ \\
\hline Mean & 3.18 & 1.89 & 1.98 & 2.04 & 1.91 & 3.23 & 2.73 & 2.10 & 2.08 \\
\hline Maximum & 5.98 & 5.01 & 3.4 & 5.53 & 4.60 & 5.93 & 5.02 & 3.58 & 5.26 \\
\hline Minimum & 0.73 & 0.25 & 0.66 & 0.69 & 0.28 & 0.76 & 0.61 & 0.69 & 0.26 \\
\hline $\mathrm{SD}(\mathrm{m})$ & 1.10 & 0.92 & 0.53 & 0.55 & 0.86 & 1.12 & 0.95 & 0.61 & 1.02 \\
\hline $\mathrm{CV} \%$ & 34.59 & 9.2 & 26.71 & 27.0 & 45.02 & 34.7 & 34.8 & 29.1 & 49.0 \\
\hline
\end{tabular}

P.M-Pre Monsoon, M-Monsoon, Post M-Post Monsoon

\section{Development of water resources and its impact on agricultural productivity}

The water harvesting structures were designed for capacity of $1500 \mathrm{~m}^{3}$ each. The dug well depth was decided based on the availability of top layer aquifer and it was constructed upto $6.65 \mathrm{~m}$ depth with 3 meter diameter of the well. The depth of bore well was 15 meter and it was constructed near to the water harvesting structures. During the months from January to May, water harvesting structures were used for raring of fish. However, it was used for growing vegetable / high value cash crop during rabi and summer season. The data pertaining to irrigation requirement, water use efficiency, water productivity, and overall economic return obtained by the farmers is described below.

\section{Dug well command area}

The dug well water used for growing three crops i.e. jute-Paddy-Onion in a year. Earlier, most of the farmers follows two crops in a year and obtain very low crop yield under rainfed condition. The economic return of Jute - Paddy and onion revealed that jute was grown during March end to July end produced about $3029 \mathrm{~kg}$ fibre yield per ha with net return of Rs 13546 per ha. After harvest of this crop Khandagiri a short duration paddy variety was planted and continued up to October end, which produced $3125 \mathrm{~kg} / \mathrm{ha}$ grain yield with net return of Rs 9020 per ha. After Kharif paddy again local onion variety was taken and produced bulb yield of $6667 \mathrm{~kg} /$ ha with net return of Rs 45006 per ha. Thus with three crops in a year under irrigated condition about Rs 67572 /ha was obtained. There was no severe depletion of well water depth even during hot summer month as the farmers used $2 \mathrm{hp}$ kerosene operated pump when electric power supply was not regular. Regarding irrigation requirement and water use efficiency, the ET based crop has more water use efficiency than irrigation based. In case of Jute crop it was reverse as irrigation was not applied once rainfall received (Table 4). 
Table 4: Irrigation scheduling and water requirement of crops

\begin{tabular}{|l|l|l|l|l|l|l|}
\hline Crop & Duration & ET crop mm & $\begin{array}{l}\text { Irrigation } \\
\text { water } \mathrm{mm}\end{array}$ & Rainfall, $\mathrm{mm}$ & $\begin{array}{l}\text { WUE ETcrop base } \\
\text { Kg/ha-mm }\end{array}$ & $\begin{array}{l}\text { WUE irrig. Base } \\
\mathrm{Kg} / \mathrm{ha}-\mathrm{mm}\end{array}$ \\
\hline Jute & $\begin{array}{l}25.3 .2007 \text { to } \\
30.7 .2007\end{array}$ & 373.31 & 310 & 877 & 8.11 & 9.77 \\
\hline Onion & $\begin{array}{l}27.10 .2007 \text { to } \\
10.3 .2008\end{array}$ & 329.8 & 380 & 58 & 20.2 & 17.5 \\
\hline
\end{tabular}

During 2008-2009, Jute was planted on $27^{\text {th }}$ April 2008 after pre -sowing irrigation and subsequent irrigation was provided in the month of May 2008. After harvest of jute crop on $17^{\text {th }}$ August, 2008, paddy seedling were grown in separate field and planted in main field on August 28, 2008 and harvested on $5^{\text {th }}$ December 2008. After that onion and garlic seedling was planted on $17^{\text {th }}$ December, 2008 and harvested on April 8, 2009. From these three crops, the best combination was Jute-rice and garlic in which the total net return was Rs.1,10,839/ha. When five irrigations was applied to onion and garlic during rabi and two irrigations to jute crop during summer season the groundwater remained at shallow depth. The farmers adopted the same cropping system as they had adopted during 2008-09 in dugwell command. The yield of paddy was not satisfactory due to delayed planting. After that onion seedling was planted on $17^{\text {th }}$ December2009 and harvested on April $8^{\text {th }}, 2010$. As the planting of onion was late, the crop yield was also quite low but overall production and economic return was high as compared to single crop system. In this case the total net return of three cropping system was Rs. 103340 /ha. If garlic crop is grown under three cropping system the net return came Rs. 108405/ha (Table 5). This can be further improved if Jute crop is sown early and harvested in end of July on after week of August every year. In onion crop five irrigations were provided during complete crop growth period.

Table 5: Cropping pattern and economic return

\begin{tabular}{|c|c|c|c|c|c|}
\hline Dug well & Crop name & $\begin{array}{l}\text { Crop yield } \\
\mathrm{Kg} / \text { ha }\end{array}$ & $\begin{array}{l}\text { Total } \\
\text { Expenditure } \\
\text { Rs/ ha }\end{array}$ & $\begin{array}{l}\text { Gross return } \\
\text { Rs / ha }\end{array}$ & $\begin{array}{l}\text { Net return } \\
\text { Rs / ha }\end{array}$ \\
\hline \multirow{6}{*}{$\begin{array}{l}\text { Total rabi area } 2360 \\
\mathrm{~m}^{2}\end{array}$} & Jute (Kharif) & 2840 & 32035 & 56800 & 24765 \\
\hline & Paddy kharif(Naveen) & 3025 & 17750 & 29040 & 11290 \\
\hline & Onion $(r a b i)$ & 9120 & 33035 & 100320 & 67285 \\
\hline & Garlic (rabi) & 7140 & 34750 & 107100 & 72350 \\
\hline & $\begin{array}{l}\text { Three cropping system (jute+paddy+ } \\
\text { onion) }\end{array}$ & & 82820 & 186160 & 103340 \\
\hline & $\begin{array}{l}\text { Three cropping } \\
\text { system (Jute+paddy+ garlic) }\end{array}$ & & 84535 & 192940 & 108405 \\
\hline
\end{tabular}

In case of $2^{\text {nd }}$ dug well command area, short duration paddy varieties Khandagiri was grown during June 20, 2008 to October 9, 2008. Crop yield and economic return on paddy revealed that the grain yield was $3032 \mathrm{~kg} / \mathrm{ha}$. The net return from the paddy crop during kharif season was Rs.7774/ha. After harvest of kharif paddy, different vegetable crops were grown in $1400 \mathrm{~m}^{2}$ area. The result showed that out of all six vegetable crop, tomato gave maximum return of Rs. 41200/ha followed by potato (Rs 31180/ha). After harvest of these small duration vegetable crop, the farmers kept the land fallow due to social constraints instead of taking third crop during summer season. In this open well command area, three crops can be taken up without further reduction of groundwater table. Under two hundred percent cropping system, paddy +onion system recorded maximum net profit of Rs 49079 /ha followed by paddy + tomato (Rs. 48974 /ha). After harvest of rabi vegetable, growing of summer crop is quite feasible since the field of potato and radish was almost ready for summer crop. The most profitable summer crop is bitter gourd and water melon.

\section{Bore well command area}

During kharif 2007-08, 18 farmers were involved in the command are. They had taken paddy crop variety Moti (long duration), Naveen \& Swarna (medium duration) \& Satabdi (short duration) during kharif season 2007. At the time of nursery, they had irrigated the crops through tube well water for preparation of nursery bed \& subsequently grown with rainwater. Most of the farmers had started transplanting rice seedlings in second week of July 2007 and continued up to first week of August 2007. Harvesting of paddy crops were started in October and continued even up to first week of December, 2007. The results revealed that the long duration paddy variety Moti performed well and gave highest crop yield of $4875 \mathrm{~kg} / \mathrm{ha}$. After harvest of paddy crop, farmers grew different vegetable crops viz. onion, tomato, potato. Irrigations were provided through tube well water as per irrigation schedules. In onion the crop yields was recorded to the extent of $5000 \mathrm{~kg} / \mathrm{ha} \mathrm{ha} \mathrm{with}$ net economic return of Rs18600 per ha. In case of Tomato (variety BT 10), the crop yield was $15625 \mathrm{~kg} / \mathrm{ha}$ and net return was Rs 42188/ha In case of potato the crop yield was $19687 \mathrm{~kg} / \mathrm{ha}$ and net return was Rs 34375/ha. So with paddy based cropping system having bore well water two hundred percent cropping intensity with high 
value cash crop could be taken up provided market facility exists in nearby places particularly for tomato crop as it is highly perishable vegetable crop.

Out of six vegetable crops, potato crop had highest irrigation water use efficiency, as it is modified stem and developed underground. This crop is bulky/ tuberous which has very high utilization efficiency as compared to other vegetable crops. Among all vegetable crops, green chilli had very low water use efficiency. The water productivity ( $\mathrm{kg}$ fruit yield/ $\mathrm{m}^{3}$ of water used) is highest in potato followed by brinjal. The water productivity of potato in distributary's no 5 over the average of 12 villages was $4.23 \mathrm{~kg}$ yield $/ \mathrm{m}^{3}$ of crop ET, but from the present study, the water productivity was enhanced to $8.413 \mathrm{~kg}$ fruit $/ \mathrm{m}^{3}$ of crop ET and $6.613 \mathrm{~kg}$ fruit/ $\mathrm{m}^{3}$ of irrigation water applied. In other vegetable crops the water productivity of the study area was comparatively more than that of average value of 12 villages. During rabi 2009-2010, after harvest of paddy, farmers grew tomato, potato, brinjal and Ladies' finger. Irrigations were provided through tube well water as per irrigation schedules. The crop yields of potato was $18350 \mathrm{~kg}$ /ha with net economic return of Rs 28280/ha. In case of tomato (Hybrid) the crop yield was 15670 to $17750 \mathrm{~kg} / \mathrm{ha}$ with net return of Rs 26560 to 34110/ ha. Among all vegetable crops, brinjal crop gave more profit (Rs 75270/ha) followed by Lady Finger (Rs 57780/ha.).

In water harvesting structures, during the experimentation, the water use efficiency and water productivity of different vegetable crops, paddy crops grown under open well command and bore well command has been analyzed based on crop yield data and irrigation water used by the crops and crop ET for the growing season. Low input-based scientific fish culture operation was carried out for two crops using surface and groundwater for two consecutive years (2008-10) in two earthen ponds of $282 \mathrm{~m}^{2}$ each. After 240 days of rearing, $1^{\text {st }}$ crop harvesting was carried out in the month of May, 2009. Similarly, after 240 days of rearing, $2^{\text {nd }}$ crop harvesting was carried out in the month of May, 2010. This increased the productivity upto 2.11 t/ha/240days.

\section{Conclusion}

Conjunctive use planning of irrigation through bore well, dug wells and ponds on farmers' participatory approach in tail reach of the canal command areas could increase cropping intensity from $151 \%$ to $300 \%$ with high value and less water requirement crops. Interventions showed that during long dry spell period in kharif season and non availability of canal water, use of groundwater up to $20 \%$ of the crop water demand could enhance crop yield up to $21 \%$. Utilizing water from dug well, for three crops (short duration rice- potato/ radishbitter gourd) in a year recorded highest net return of Rs 87368/ha against Rs 90,031/ha for two crops (rice brinjal) without depletion of groundwater level. Further, highest water productivity (kg fruit yield $/ \mathrm{m}^{3}$ of water used) was observed in potato (6.67-8.41) followed by brinjal (4.06-4.42).

\section{Reference}

[1] Anonymous,(2008). Report of Directorate of Economics and Statistics, Government of Odisha.

[2] Bredehoeft, John D. and Young, Robert A. (1983). Conjunctive use of groundwater and surface water for irrigated agriculture: Risk aversion. Water Resources Research, Vol. 19 (5), pp.1111-1121.

[3] CGWB. (2010). Groundwater Scenario of India, Ministry of Water Resources, Government of India, 2010.

[4] Cummings, R. G. and Winkle, D. (1974). Water Resources Management in Arid Environments, Water Resources Research . Vol. 10 (5), pp. 909-915.

[5] FAO Irrigation and drainage paper- 56, Crop Evapotranspiration (guidelines for computing crop water requirements)

[6] Foster S and Steenbergen F van, (2011). Conjunctive groundwater use: a 'lost opportunity' for water management in the developing world? Hydrogeology Journal. DOI 10.1007/s10040-011-0734-1.

[7] Khepar, S. D. and Chaturvedi, M. C. (1982). Optimum cropping and groundwater management, Water Resources Bulletin. Vol. 18(4), 655-660.

[8] Panda, S. N., Khepar, S. D. and Kaushal, M. P. (1985). Stochastic irrigation planning: An application of chance constrained linear programming, Journal of Agric. Engineering, ASCE, 22(2), 93-105.

[9] Sethi, L. N., Sudhindra N. Panda And Manoj k. Nayak (2006), Optimal crop planning and water resources allocation in a coastal groundwater basin, Orissa, India, Agricultural Water Management, 83, pp. 209-220.

[10] Shah T, Dargouth S and Dinar A, (2006). Conjunctive use of groundwater and surface water. World Bank, Agricultural and Rural Development Notes. Issue 6 February 2006.

[11] Shankar, P.S.V, H. kulkarni, S.R. Krishna (2011), India's groundwater Challenge and the way forward, Economic \& Political Weekly, January 8, Vol xlvi 38 no 2.

[12] Tsur, Y, (1990). The stabilization role of groundwater when surface water supplies are uncertain: the implications for groundwater development. Water resources Research, Vol 26, No 5 